\title{
Mode of Action of Miconazole on Candida albicans: Effect on Growth, Viability and K+ Release
}

\author{
By JANE E. COPE $\dagger$ \\ University of Cambridge Department of Biochemistry, \\ Tennis Court Road, Cambridge
}

(Received 22 October 1979; revised 2 January 1980)

\begin{abstract}
Miconazole at $10 \mu \mathrm{g} \mathrm{ml}^{-1}$ inhibited the growth of exponential phase cultures of Candida albicans and released intracellular $\mathrm{K}^{+}$. Higher concentrations of miconazole were, however, required to cause cell death: at neutral $\mathrm{pH}$, complete killing occurred at $30 \mu \mathrm{g} \mathrm{ml}^{-1}$, while at $\mathrm{pH} 3.0$ or 4.5 , there was only partial killing with miconazole up to $80 \mu \mathrm{g} \mathrm{ml}^{-1}$. Efficient killing of $C$. albicans by miconazole occurred both at low temperature and when cells were incubated in buffer alone. It is proposed that both the fungistatic and fungicidal actions of miconazole are due to its direct interaction with the cellular membranes of $C$. albicans rather than to an inhibition of biochemical reactions. Divalent cations protected C. albicans from both the fungistatic and fungicidal effects of miconazole and this was probably due to a competition between the ions and miconazole in its positively charged form for negatively charged binding sites. Candida albicans increased in resistance to miconazole-induced $\mathrm{K}^{+}$release during the stationary phase of a batch culture. Development of this resistance required efficient aeration.
\end{abstract}

\section{INTRODUCTION}

Miconazole is a synthetic imidazole derivative with broad-spectrum antimicrobial action against fungi and Gram-positive bacteria (Godefroi et al., 1969). It has been used successfully in the treatment of topical fungal infections including vaginal candidiasis (Godts et al., 1971), tinea pedis (Brugmans et al., 1970), onychomycosis (Achten et al., 1977) and pityriasis versicolor (Van Cutsem \& Reyntjens, 1978). It has also been partially successful in the treatment of systemic mycoses (Stevens, 1977). Miconazole affects membrane function in a number of systems. In Candida albicans, alterations in the transport properties of the plasma membrane were found at concentrations of miconazole lower than that required to inhibit growth (Van den Bossche, 1974). Leakage of $\mathrm{K}^{+}$and ultraviolet-absorbing materials has also been reported (Swamy et al., 1974). Ultrastructural studies have shown that miconazole causes widespread disruption of the cellular membranes of $C$. albicans (De Nollin \& Borgers, 1974, 1976). In addition, miconazole affects the function in vitro of erythrocytes (Swamy et al., 1976b), lysosomes (Swamy et al., 1976a) and mitochondria (Dickinson, 1977). Yamaguchi $(1977,1978)$ suggested that miconazole associated with free unsaturated fatty acids and those within phospholipids and thus could disrupt membrane structure. However, Van den Bossche et al. (1978) have suggested that the effect of miconazole on cell membranes in C. albicans is due to inhibition of sterol demethylation thus preventing the synthesis of ergosterol, the major sterol in fungal membranes. De Nollin et al. (1977) observed a drop in the amount of peroxidase enzymes in C. albicans and Saccharomyces cerevisiae following incubation with miconazole and suggested that cell death was due to a build-up of $\mathrm{H}_{2} \mathrm{O}_{2}$.

$\dagger$ Present address: Department of Histology and Cell Biology (Medical), University of Liverpool, P.O. Box 147, Liverpool L69 3BX. 
The present study was carried out to extend our knowledge of the effect of miconazole on the growth and viability of $C$. albicans and the loss of $\mathrm{K}^{+}$from this organism.

\section{METHODS}

Organisms and growth conditions. Candida albicans strains 6406, 723 and 6979 were obtained from the Mycological Reference Laboratory, London School of Hygiene and Tropical Medicine. Unless otherwise stated, all experiments were carried out using strain 6406. Cultures were maintained on slopes of Yeast Morphology Agar (Difco) (YMA) and stored at $4{ }^{\circ} \mathrm{C}$. Unless otherwise stated, liquid cultures were grown in the synthetic yeast medium of Davies (1953) containing $2 \%(\mathrm{w} / \mathrm{v})$ glucose (SYG medium). Yeast Nitrogen Base (Difco) containing $2 \%$ (w/v) glucose (YNBG medium) was also used. Weekly inoculum cultures were prepared by inoculating $100 \mathrm{ml}$ SYG medium from the slopes, and these were stored at $4{ }^{\circ} \mathrm{C}$ after overnight incubation at $37^{\circ} \mathrm{C}$ in an orbital incubator.

Measurement of inhibition of growth by miconazole. To $100 \mathrm{ml} \mathrm{SYG} \mathrm{medium} \mathrm{in} 250 \mathrm{ml}$ conical flasks was added a sufficiently large inoculum to give an initial $A_{600}$ of about $0 \cdot 1$. After 4 to $5 \mathrm{~h}$ in an orbital incubator at $37^{\circ} \mathrm{C}$, the growth rate was exponential. Miconazole (kindly given by Janssen Pharmaceutica, Beerse, Belgium), dissolved in methanol at $5 \mathrm{mg} \mathrm{ml}^{-1}$, was then added to the cultures to give the required concentration. Further growth was followed turbidimetrically at $600 \mathrm{~nm}$.

Mesaurement of release of $\mathrm{K}^{+}$by miconazole. Release of $\mathrm{K}^{+}$was determined using a $\mathrm{K}^{+}$-sensitive electrode (type BH 115, Electronic Instruments Ltd, Richmond, Surrey) connected to a measuring unit C33B-2 and Vibron electrometer 33B-2 (Electronic Instruments) with output to a potentiometric recorder, as described by Gale (1974). Cultures of $C$. albicans (either 11 or $100 \mathrm{ml}$ ) were harvested, washed twice with $0.05 \mathrm{M}$ Tris/ $\mathrm{HCl}$ buffer $\mathrm{pH} 7.5$ (made with deionized water) and resuspended in this buffer to give $10 \mathrm{mg} \mathrm{dry} \mathrm{wt} \mathrm{ml} \mathrm{m}^{-1}$ $\left(A_{600}=33\right)$. Two $\mathrm{ml}$ of this suspension was diluted into $18 \mathrm{ml}$ of the same Tris/HCl buffer $\mathrm{pH} 7.5$ in the electrode vessel, except for the experiments in which the effect of cell density on $\mathrm{K}^{+}$release was studied, when $1 \mathrm{ml}$ and $4 \mathrm{ml}$ of the stock suspension were diluted into $19 \mathrm{ml}$ and $16 \mathrm{ml}$ buffer, respectively. Miconazole was added to the cells from the stock solution in methanol and average $\mathrm{K}^{+}$release rates in $\mathrm{nmol} \mathrm{min}^{-1}(\mathrm{mg}$ cells $)^{-1}$ were calculated for each 1 min period after adding miconazole, using a previously constructed calibration curve. Release of $\mathrm{K}^{+}$from each sample was followed for up to $30 \mathrm{~min}$. The intracellular $\mathrm{K}^{+}$ content of cells was assayed by measuring the amount of $\mathrm{K}^{+}$released on incubation of $2 \mathrm{ml}$ of the washed cell suspension in a boiling water bath for 20 min prior to diluting into $18 \mathrm{ml}$ buffer in the electrode vessel.

Measurement of loss of viability induced by miconazole. To produce populations of single cells suitable for viability counting, cultures were incubated at $37^{\circ} \mathrm{C}$ without shaking. Initially, the effect of miconazole was tested directly in the culture medium, while, for studying the effect of $\mathrm{pH}$ and cell density, samples of the cells were harvested, washed and resuspended in Tris/HCl buffer pH 7.5 and $\mathrm{Na}_{2} \mathrm{HPO}_{4} /$ citric acid buffers pH 4.5 and 3.0, at $A_{600}$ values of 2.0 and 6.0. Miconazole, dissolved in methanol as described above, was added to $10 \mathrm{ml}$ of cell suspension in glass tubes (diam. approx. $15 \mathrm{~mm}$ ) and incubated at $37^{\circ} \mathrm{C}$. At appropriate times, $0.5 \mathrm{ml}$ was removed from each tube, diluted into $4.5 \mathrm{ml}$ sterile $0.85 \%(\mathrm{w} / \mathrm{v}) \mathrm{NaCl}$, and treated for $2 \mathrm{~min}$ in a Sonicleaner type 6441 A (Dawe Instruments Ltd, Western Avenue, Acton, London W3). Cell suspensions were diluted a further $10^{4}$ or $10^{5}$ times in sterile saline before spreading $0.5 \mathrm{ml}$ on to each of three YMA plates. After $24 \mathrm{~h}$ at $37^{\circ} \mathrm{C}$, colonies were counted and the number of viable units per $\mathrm{ml}$ of original suspension was calculated. The total number of cells in the first dilution was counted in an Improved Neubauer haemocytometer after sonication for $2 \mathrm{~min}$. The counting was done using phase contrast microscopy and approximately 600 cells were counted in each sample. Percentage viability was calculated from the ratio of viable to total count.

\section{RESULTS}

\section{Effect of miconazole on the growth of C. albicans}

When added to a culture of $C$. albicans in mid-exponential phase, miconazole at $10 \mu \mathrm{g} \mathrm{ml}^{-1}$ caused complete cessation of growth, while at $1 \mu \mathrm{g} \mathrm{ml}^{-1}$ growth continued unchecked. At intermediate concentrations, there was partial inhibition of growth (Fig. 1a). The degree of inhibition by miconazole at $10 \mu \mathrm{g} \mathrm{ml}^{-1}$ was greater the earlier in the exponential phase that it was added, but if it was added before exponential growth was established, there was less inhibition (Fig. $1 b$ ). The decreased effect of miconazole when added in the later stages of growth may have been due, at least in part, to an effect of the increased cell density, since when miconazole was added to a series of cultures inoculated at different cell densities, the inhibition was greater the lower the cell density (Fig. 1c). 

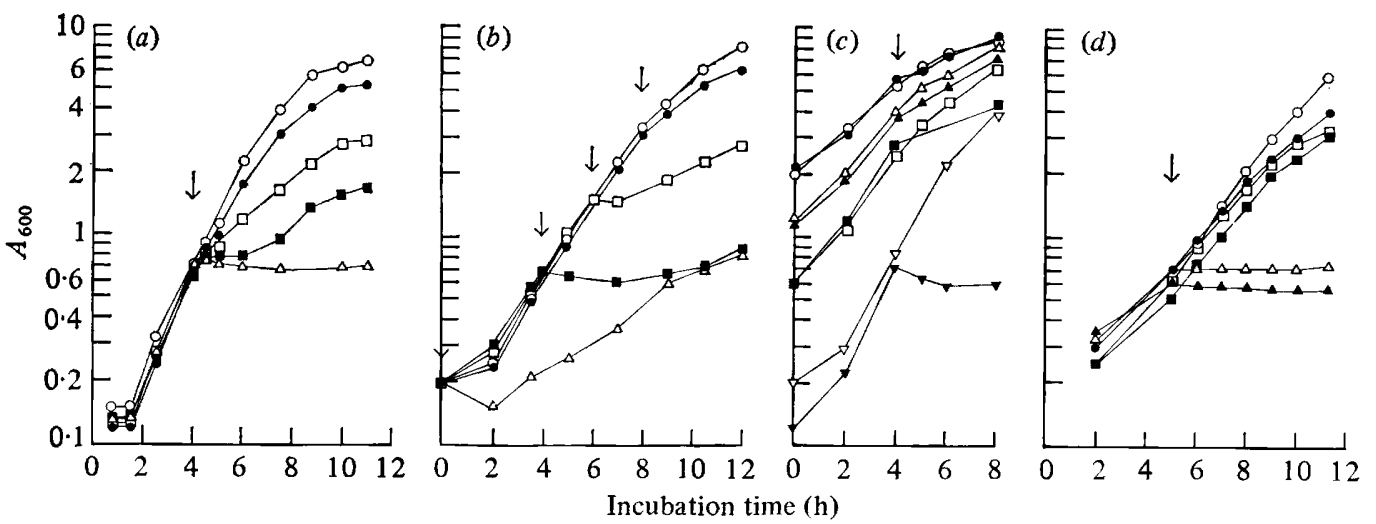

Fig. 1. Effect of miconazole on the growth of C. albicans in $2 \%(\mathrm{w} / \mathrm{v})$ glucose synthetic yeast (SYG) medium. (a) After $4 \mathrm{~h}$ incubation, miconazole was added to give concentrations of $10(\triangle), 5(\square)$, $3(\square), 1$ (O) or $0(\bigcirc) \mu \mathrm{g} \mathrm{ml}^{-1}$. (b) Miconazole was added to give $10 \mu \mathrm{g} \mathrm{ml}^{-1}$ after incubation for $0 \mathrm{~h}(\triangle), 4 \mathrm{~h}(\square), 6 \mathrm{~h}(\square)$ or $8 \mathrm{~h}(\bigcirc)$; control without miconazole $(\mathrm{O})$. (c) After $4 \mathrm{~h}$ incubation, miconazole was added to give $10 \mu \mathrm{g} \mathrm{ml}^{-1}$ to cultures having approximate $A_{600}$ values of $0 \cdot 7(\boldsymbol{\nabla})$, $2.5(\boldsymbol{D}), 3.5(\mathbf{A})$ or $5.5(\mathbf{O})$; open symbols are for the respective controls without miconazole. (d) After $5 \mathrm{~h}$ incubation, miconazole was added to give $10 \mu \mathrm{g} \mathrm{ml}^{-1}$ to cultures containing $45 \mathrm{~mm}$ $\mathrm{MgCl}_{2}$ and/or $85 \mathrm{~mm}-\mathrm{KCl}$ : miconazole plus $\mathrm{KCl}(\boldsymbol{\Delta})$, miconazole plus $\mathrm{MgCl}_{2}(\mathbf{O})$, miconazole plus $\mathrm{MgCl}_{2}$ plus $\mathrm{KCl}(\square)$, miconazole alone $(\triangle), \mathrm{MgCl}_{2}$ plus $\mathrm{KCl}(\square)$, control with no additions (O).

Addition of either $\mathrm{Mg}^{2+}$ or $\mathrm{Ca}^{2+}$ to $\mathrm{SYG}$ medium prevented miconazole from inhibiting the growth of $C$. albicans. The concentration of divalent cations required to exhibit a protective effect depended upon the concentration of miconazole to which C. albicans was exposed. Divalent cations were only effective when added to a culture of $C$. albicans before or immediately after adding miconazole. An example of the protective effect of $\mathrm{MgCl}_{2}$, and the failure of $\mathrm{KCl}$ to have a similar effect, is given in Fig. $1 d$. Miconazole at $10 \mu \mathrm{g} \mathrm{ml}^{-1}$ inhibited exponentially growing static cultures of $C$. albicans as completely as shaken cultures.

\section{Effect of miconazole on the viability of $C$. albicans}

When added to samples of an early-exponential phase static culture of $C$. albicans, miconazole was fungicidal at 30 to $40 \mu \mathrm{g} \mathrm{ml}^{-1}$ but not at $20 \mu \mathrm{g} \mathrm{ml}^{-1}$. At $37^{\circ} \mathrm{C}$ killing was almost complete within $2 \mathrm{~h}$ (Table $1 \mathrm{a}$ ); at $1{ }^{\circ} \mathrm{C}$ the rate of killing was slower, although after $24 \mathrm{~h}$ there was no difference in the percentage of cells surviving. Cultures at the end of the growth phase were much more resistant to killing by miconazole and an appreciable percentage survived $72 \mathrm{~h}$ contact with $80 \mu \mathrm{g} \mathrm{ml}^{-1}$ (Table $1 \mathrm{~b}$ ). This was apparently due to the drop in $\mathrm{pH}$ which occurred during growth rather than to the increase in cell density, since a threefold difference in cell density did not affect the fungicidal activity of miconazole, whereas there was a marked $\mathrm{pH}$ dependency (Table 2). The $\mathrm{pH}$ of cultures of $C$. albicans grown in SYG medium dropped from an initial value of 6.5 to about 3.0 during growth. As with the effect on growth inhibition, $\mathrm{Mg}^{2+}$ but not $\mathrm{K}^{+}$protected $C$. albicans from the fungicidal action of miconazole.

\section{Effect of miconazole on $K^{+}$release from $C$. albicans}

Kerridge et al. (1976b) reported that $C$. albicans 6406 developed a resistance to miconazole-induced $\mathrm{K}^{+}$release during the stationary phase of a shaken batch culture. This was confirmed for cells harvested at $24 \mathrm{~h}$ (Fig. $2 a$ ), $48 \mathrm{~h}$ (Fig. $2 b$ ) and $72 \mathrm{~h}$ after inoculation. The release of $\mathrm{K}^{+}$from cells harvested after $72 \mathrm{~h}$ incubation was negligible in the presence of miconazole up to $40 \mu \mathrm{g} \mathrm{ml}^{-1}$. Resistant cells regained their sensitivity to miconazole on re-inoculation into fresh medium. 
Table 1. Survival of C. albicans grown for $15 \mathrm{~h}$ and $48 \mathrm{~h}$ at $37^{\circ} \mathrm{C}$ in static culture when exposed at $37^{\circ} \mathrm{C}$ to miconazole

(a) 15 h (exponential phase) culture $\left(A_{600}=2 \cdot 6\right)$

Miconazole
$\left(\mu \mathrm{g} \mathrm{ml}^{-1}\right)$
0
20
30
40

Percentage of cells surviving after exposure for:

$\begin{array}{rrrrr}0 \mathrm{~h} & 2 \mathrm{~h} & 4 \mathrm{~h} & 8 \mathrm{~h} & 24 \mathrm{~h} \\ 100 & 61 & 50 & 60 & 37 \\ 90 & 26 & 24 & 25 & 31 \\ 69 & 6 & 1 & 1 & <1 \\ 72 & 2 & 2 & <1 & <1\end{array}$

(b) 48 h (early-stationary phase) culture $\left(A_{600}=6.0\right)$

Miconazole
$\left(\mu \mathrm{g} \mathrm{ml}^{-1}\right)$

0

10

20

40

80

Percentage of cells surviving after exposure for:

$\begin{array}{rcc}24 h & 48 h & 72 h \\ 96 & 103 & 85 \\ 106 & 58 & 53 \\ 105 & 66 & 45 \\ 114 & 67 & 39 \\ 76 & 27 & 13\end{array}$

Table 2. Effect of cell density and $p H$ on the ability of miconazole to kill C. albicans grown for $15 \mathrm{~h}$ in static culture (exponential phase) when exposed at $37^{\circ} \mathrm{C}$ to miconazole for $24 \mathrm{~h}$ after washing and resuspension in buffer

Percentage of cells surviving

Miconazole
$\left(\mu \mathrm{g} \mathrm{ml}^{-1}\right)$

0

10

20

40

80

\begin{tabular}{|c|c|c|}
\hline \multicolumn{3}{|c|}{ Initial $A_{000}=6.0$} \\
\hline pH 3.0 & $\mathrm{pH} 4.5$ & $\mathrm{pH} 7 \cdot 5$ \\
\hline 63 & 40 & 60 \\
\hline 64 & 42 & 29 \\
\hline 62 & 43 & 15 \\
\hline 52 & 39 & $<1$ \\
\hline 59 & 26 & $<1$ \\
\hline
\end{tabular}

\begin{tabular}{|c|c|c|}
\hline \multicolumn{3}{|c|}{ Initial $A_{600}=2 \cdot 0$} \\
\hline $\mathrm{pH} 3 \cdot 0$ & $\mathrm{pH} 4.5$ & $\mathrm{pH} 7 \cdot 5$ \\
\hline 78 & 50 & 78 \\
\hline 77 & 44 & 16 \\
\hline 60 & 46 & 1 \\
\hline 52 & 34 & $<1$ \\
\hline 54 & 8 & $<1$ \\
\hline
\end{tabular}

Gale (1974), in using $\mathrm{K}^{+}$release measurements to study the effect of amphotericin B methyl ester (AME) on C. albicans, defined a standard release concentration (SRC) of $\mathrm{AME}$ as the amount required to raise the $\mathrm{K}^{+}$release rate by $1 \mathrm{nmol} \mathrm{min}^{-1}\left(\mathrm{mg}\right.$ cells) ${ }^{-1}$ above the background leakage rate in $8 \mathrm{~min}$. This is not a suitable measure of miconazole action since this antifungal agent produces an increase followed by a decrease in $\mathrm{K}^{+}$release rate in contrast to $\mathrm{AME}$ which causes the $\mathrm{K}^{+}$release rate to increase until the cells become severely depleted of $\mathrm{K}^{+}$. An SRC can be defined more conveniently in terms of the concentration of miconazole required to give a maximum $\mathrm{K}^{+}$release rate of $1 \mathrm{nmol} \mathrm{min}^{-1}(\mathrm{mg} \mathrm{cells})^{-1}$ above the background leakage rate. Although SRCs are arbitrarily defined, sensitivities can be quoted in terms analogous to minimum growth inhibitory concentrations measured by traditional methods. The SRC of miconazole increased in a linear fashion from 1 to $10 \mu \mathrm{g} \mathrm{ml}^{-1}$ for $C$. albicans in exponential phase to about $40 \mu \mathrm{g} \mathrm{ml}^{-1}$ for cells grown for $72 \mathrm{~h}$ in shaken batch culture. Thereafter, there was a steeper rise in the SRC which was found to be due to cell death and loss of intracellular $\mathrm{K}^{+}$. However, the increase in resistance to miconazole-induced $\mathrm{K}^{+}$release which occurred between the end of the growth phase and the point of cell death in culture could not be accounted for in terms of altered intracellular $\mathrm{K}^{+}$content.

In the same way as the growth inhibitory activity of miconazole was less, the greater 


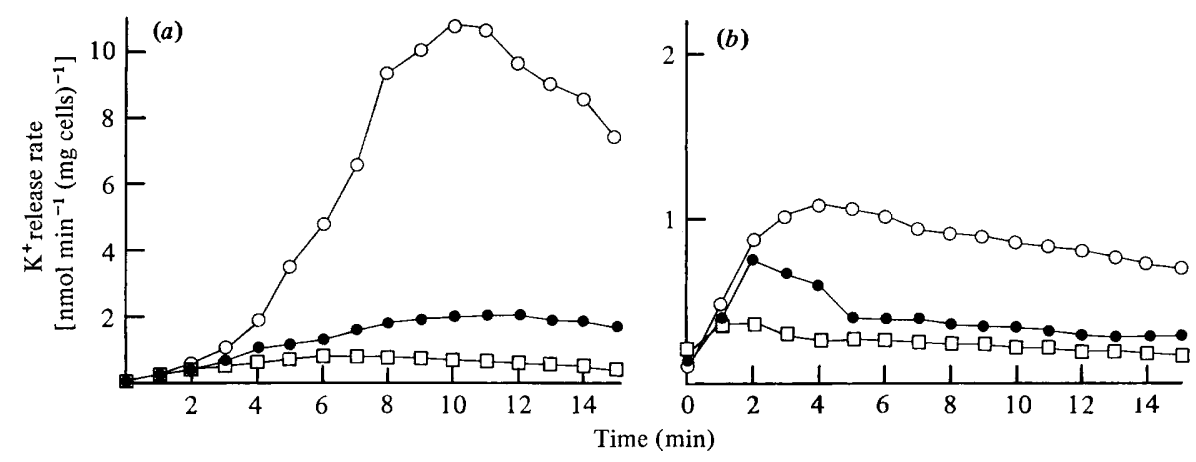

Fig. 2. Pattern of miconazole-induced $\mathrm{K}^{+}$release from $C$. albicans harvested from shaken batch culture in $(a)$ early-stationary phase $(24 \mathrm{~h}$ growth) and $(b)$ mid-stationary phase ( $48 \mathrm{~h}$ growth). Miconazole was added to give $40(\bigcirc), 20(\bigcirc)$ or $10(\square) \mu \mathrm{g} \mathrm{ml}^{-1}$. Note the different ordinate scales in $(a)$ and $(b)$.

Table 3. Effect of the density of cell suspensions on miconazole-induced $K^{+}$release from $C$. albicans

\begin{tabular}{|c|c|c|c|}
\hline Phase of growth & $\begin{array}{c}\text { Cell density } \\
\left(\mathrm{mg} \text { dry wt } \mathrm{ml}^{-1}\right)\end{array}$ & $\begin{array}{l}\text { Miconazole } \\
\left(\mu \mathrm{g} \mathrm{ml}^{-1}\right)\end{array}$ & $\begin{array}{c}\text { MRR }^{*} \\
{\left[\mathrm{nmol} \min ^{-1}(\mathrm{mg} \text { dry wt })^{-1}\right]}\end{array}$ \\
\hline $\begin{array}{l}\text { Early-exponential } \\
\qquad(6 \mathrm{~h})\end{array}$ & $\begin{array}{l}2 \cdot 0 \\
1 \cdot 0 \\
0.5\end{array}$ & $\begin{array}{l}10 \\
10 \\
10\end{array}$ & $\begin{array}{l}0.49 \\
1.90 \\
6.40\end{array}$ \\
\hline $\begin{array}{l}\text { Mid-stationary } \\
\quad(48 \mathrm{~h})\end{array}$ & $\begin{array}{l}2 \cdot 0 \\
1 \cdot 0 \\
0 \cdot 5\end{array}$ & $\begin{array}{l}20 \\
20 \\
20\end{array}$ & $\begin{array}{l}0 \cdot 65 \\
1 \cdot 28 \\
2 \cdot 72\end{array}$ \\
\hline
\end{tabular}

* MRR, Maximum rate of $\mathrm{K}^{+}$release, determined as $\mathrm{nmol} \mathrm{min}^{-1}$ ( $\mathrm{ml}$ buffer ${ }^{-1}$ and converted to $\mathrm{nmol} \mathrm{min}^{-1}$ (mg dry wt cells) ${ }^{-1}$.

the density of growth (Fig. $1 c$ ), so its ability to release $\mathrm{K}^{+}$from $C$. albicans was less, the greater the density of the cell suspension (Table 3 ).

Candida albicans strains 723 and 6979 also developed resistance to miconazole-induced $\mathrm{K}^{+}$release during the stationary phase of a shaken batch culture and suffered cell death and loss of intracellular $\mathrm{K}^{+}$after $3 \mathrm{~d}$ in culture. Similar behaviour was observed when C. albicans 6406 was grown in YNBG medium instead of SYG medium. These phenomena are therefore not due entirely to either the strain of organism or the growth medium used.

Increase in resistance to miconazole-induced $\mathrm{K}^{+}$release did not occur during the stationary phase of static cultures of $C$. albicans. The SRC for miconazole increased from about $1 \mu \mathrm{g} \mathrm{ml}^{-1}$ for cells from exponential phase static cultures to about $10 \mu \mathrm{g} \mathrm{ml}^{-1}$ at the end of the growth phase ( 2 to $3 \mathrm{~d}$ incubation). There was then no change in SRC and no cell death in cultures for up to $18 \mathrm{~d}$ (longer periods were not studied), both in contrast to shaken batch cultures.

Sensitivity of $C$. albicans to miconazole-induced $\mathrm{K}^{+}$release during the exponential phase of shaken batch cultures depended on the culture volume. All cultures were inoculated with cells from an early-stationary phase culture with an SRC of about $10 \mu \mathrm{g} \mathrm{ml}^{-1}$. In $100 \mathrm{ml}$ cultures, there was a decrease in the SRC to about $1 \mu \mathrm{g} \mathrm{ml}^{-1}$ during exponential growth, followed by an increase to about $10 \mu \mathrm{g} \mathrm{ml}^{-1}$ again at the end of the growth phase. However, in 11 cultures, the SRC did not change significantly during growth, remaining at about $10 \mu \mathrm{g} \mathrm{ml}^{-1}$ throughout. The increase in SRC which occurred during the stationary phase was independent of culture volume. 


\section{DISCUSSION}

The action of miconazole on growth and $\mathrm{K}^{+}$release from $C$. albicans occurred without a delay, suggesting first that membrane damage was more likely to have been due to a direct interaction of miconazole with the plasma membrane than to an effect on ergosterol synthesis (particularly since $\mathrm{K}^{+}$release is measured in buffer which does not support growth), and second that growth inhibition was likely to have been a consequence of the leakage of intracellular contents induced by miconazole. The inverse relationship between cell density and miconazole-induced $\mathrm{K}^{+}$release was not due to metabolism to inactive product(s), since Van den Bossche et al. (1975) recovered $\left[{ }^{3} \mathrm{H}\right]$ miconazole entirely unchanged from $C$. albicans. It was probably a result of miconazole binding to the cell wall, thus depleting the buffer of miconazole, while not reaching the plasma membrane (Cope, 1980). The greater the effect of miconazole on growth of exponential phase cultures the earlier it was added was likely to have been due partly to a similar cell density effect, although other factors, e.g. $\mathrm{pH}$ and release of secondary metabolites, may also have affected growth inhibition in the constantly changing environment of the batch culture.

The action of $\mathrm{Mg}^{2+}$ in protecting $C$. albicans from miconazole-induced growth inhibition and viability loss might have been due either to an equilibration with intracellular $\mathrm{Mg}^{2+-}$, thus preventing its depletion from the cell, or to competition between $\mathrm{Mg}^{2+}$ and miconazole in its positively charged form ( $\mathrm{p} K_{\mathrm{a}}$ for the imidazole group is 6.65$)$ for negatively charged sites within the cell. Although the former adequately explains a similar protective action of a mixture of $\mathrm{Mg}^{2+}$ and $\mathrm{K}^{+}$against polyene action on yeasts (Liras \& Lampen, 1974; Kerridge et al., 1976a), it is unlikely in the present context, since miconazole causes more indiscriminate membrane damage than the polyenes, resulting in the release of small molecules and ultraviolet-absorbing materials as well as ions (Swamy et al., 1974). The effect of divalent cations may play a role in the variation in sensitivity of $C$. albicans to miconazole when incubated in different growth media (Swamy et al., 1974; Van den Bossche et al., 1975; Hoeprich \& Huston, 1976).

Higher concentrations of miconazole were required to kill $C$. albicans than to inhibit growth, suggesting that additional action is involved. Support for this is provided by the ultrastructural studies of De Nollin \& Borgers $(1974,1976)$ which showed more widespread damage to the intracellular structure of $C$. albicans at fungicidal than at fungistatic concentrations. Miconazole killed $C$. albicans under conditions where there was no growth, i.e. after washing and resuspension in buffer or when incubated at $1{ }^{\circ} \mathrm{C}$. Although killing was slower at $1^{\circ} \mathrm{C}$, it was still too efficient to be accounted for in terms of an inhibition of sterol demethylation (Van den Bossche et al., 1978) or an inhibition of synthesis of peroxidase enzymes (De Nollin et al., 1977). The sterol demethylation theory has other disadvantages since (1) it does not account for the action of miconazole against Grampositive bacteria which do not synthesize sterols, (2) external addition of demethylated sterols does not affect the minimum growth inhibitory concentration of miconazole for C. albicans (Yamaguchi, 1977) and (3) sterol demethylation appears not to be a vital function since mutants of $C$. albicans lacking demethylated sterols are viable, although their mean generation times are about twice that of the wild-type under the same conditions (Pierce et al., 1978). The results are more consistent with a cumulative effect of miconazole due to direct interaction first with the plasma membrane, causing growth inhibition, then with intracellular membranes, leading to widespread cellular disorganization and death. The action would be limited by diffusion rather than by the rates of enzyme reactions, and inhibition of biochemical reactions would occur as a consequence of membrane disruption.

The earlier observation that $C$. albicans develops a resistance to miconazole-induced $\mathrm{K}^{+}$ release during the stationary phase of a batch culture (Kerridge et al., 1976b) has been confirmed, although it was not possible to test whether there was a similar effect on miconazole-induced killing since the static cultures used for viability determination did 
not develop resistance to miconazole-induced $\mathrm{K}^{+}$release during the stationary phase. This phenotypic miconazole resistance may account for the lesser effect of miconazole on growth inhibition when added at the start of a batch culture (cells still in stationary phase) than when added during exponential growth (Fig. $1 b$ ).

The author would like to thank Dr David Kerridge, under whose supervision this work was carried out, for helpful discussion and comment, and the Science Research Council for a Research Studentship.

\section{REFERENCES}

Achten, G., Degreef, H. \& Dockx, P. (1977). Treatment of onychomycosis with a solution of miconazole $2 \%$ in alcohol. Mykosen 20, 251-256.

Brugmans, J. B., Van Cutsem, J. M. \& ThienPoINT, D. C. (1970). Treatment of long-term tinea pedis with miconazole. Archives of Dermatology $102,428-432$.

COPE, J. E. (1980). The interaction of ${ }^{3} \mathrm{H}$-miconazole with Candida albicans. Sabouraudia (in the Press).

Davies, R. (1953). Enzyme formation in Sacharomyces fragilis. I. Invertase and raffinase. Biochemical Journal 55, 484-497.

De Nollin, S. \& Borgers, M. (1974). The ultrastructure of Candida albicans after in vivo treatment with miconazole. Sabouraudia 12, 341-351.

De Nollin, S. \& Borgers, M. (1976). An ultrastructural and cytochemical study of Candida albicans after in vitro treatment with imidazoles. Mykosen 19, 317-328.

de Nollin, S., Van Belle, H., Goossens, F., ThONÉ, F. \& Borgers, M. (1977). Cytochemical and biochemical studies of yeasts after in vitro exposure to miconazole. Antimicrobial Agents and Chemotherapy 11, 500-513.

Dickinson, D. P. (1977). The effects of miconazole on rat liver mitochondria. Biochemical Pharmacology 26, 541-542.

GALE, E. F. (1974). The release of $\mathrm{K}^{+}$from Candida albicans in the presence of polyene antibiotics. Journal of General Microbiology 80, 451-465.

Godefroi, E. F., Heeres, J., Van Cutsem, J. \& JANSSEN, P. (1969). The preparation and properties of derivatives of 1-phenylimidazole. Journal of Medicinal Chemistry 12, 784-791.

Godts, P., Vermylen, P. \& Van Cutsem, J. (1971). Clinical evaluation of miconazole nitrate in the treatment of vaginal candidiasis. Arzneimittel Forschung 21, 256-257.

HoEPRICH, P. D. \& Huston, A. C. (1976). Effect of culture media on the antifungal activity of miconazole and amphotericin B methyl ester. Journal of Infectious Diseases 134, 336-341.

Kerridge, D., KoH, T. Y. \& Johnson, A. M. $(1976 a)$. Interaction of amphotericin B methyl ester with protoplasts of Candida albicans. Journal of General Microbiology 96, 117-123.

Kerridge, D., KoH, T. Y., MarriotT, M. S. \& Gale, E. F. $(1976 b)$. The production and properties of protoplasts from the dimorphic yeast Candida albicans. In Microbial and Plant Protoplasts, pp. 23-38. Edited by F. J. Peberdy, A. H. Rose, H. J. Rogers \& E. C. Cocking. London: Academic Press.

Liras, P. \& LAMPEN, J. O. (1974). Protection by $\mathrm{K}^{+}$ and $\mathrm{Mg}^{++}$of growth and macromolecule synthesis in candicidin treated yeast. Biochimica et biophysica acta 374, 159-163.

Pierce, A. M., Pierce, H. D., Unrau, A. M. \& OEHLSCHLAGER, C. (1978). Lipid composition and polyene antibiotic resistance of Candida albicans mutants. Canadian Journal of Biochemistry 56, 135-142.

Stevens, D. A. (1977). Miconazole in the treatment of systemic fungal infections. American Journal of Respiratory Diseases 116, 801-806.

Swamy, K. H. S., SiRsi, M. \& Rao, G. R. (1974). Studies on the mechanism of action of miconazole: effect on respiration and cell permeability of Candida albicans. Antimicrobial Agents and Chemotherapy 5, 420-425.

Swamy, K. H. S., Joshi, A. \& RaO, G. R. (1976a). Mechanism of action of miconazole: labilisation of rat liver lysosomes in vitro by miconazole. Antimicrobial Agents and Chemotherapy 9, 903907.

Swamy, K. H. S., SiRSI, M. \& RaO, G. R. (1976b). Studies on the mechanism of action of miconazole. II. Interaction of miconazole with mammalian erythrocytes. Biochemical Pharmacology 25, 11451150.

VAN DEN BOSSCHE, H. (1974). Biochemical effects of miconazole on fungi. I. Effects on the uptake and/or utilisation of purines, pyrimidines, nucleosides, amino acids and glucose by Candida albicans. Biochemical Pharmacology 23, 887-899.

VAN DEN Bossche, H., WILlemsens, G. \& VAN CUTSEM, J. (1975). The action of miconazole on the growth of Candida albicans. Sabouraudia 13, 63-73.

VAN den Bossche, H., Willemsens, G., Cools, W., LAUWERS, W. J. F. \& LeJeune, L. (1978). Biochemical effects of miconazole on fungi. II. Inhibition of ergosterol synthesis in Candida albicans. Chemico-Biological Interactions 21, 5978.

Van Cutsem, J. \& Reyntjens, A. (1978). Miconazole treatment of pityriasis versicolor: a review. Mykosen 21, 87-91.

YAMAGUCHI, H. (1977). Antagonistic action of lipid components of membranes from Candida albicans and various other lipids on two imidazole antibiotics, clotrimazole and miconazole. Antimicrobial Agents and Chemotherapy 12, 16-25.

YAMAGUCHI, H. (1978). Protection by unsaturated lecithin against the imidazole antimycotics, clotrimazole and miconazole. Antimicrobial Agents and Chemotherapy 13, 423-426. 